\title{
Spatial and temporal distribution of the zoobenthos community during the filling up period of Porto Primavera Reservoir (Paraná River, Brazil)
}

\author{
Jorcin, A. ${ }^{\mathrm{a} *}$, Nogueira, $M G .^{\mathrm{a}}$ and Belmont, $R .^{\mathrm{b}}$

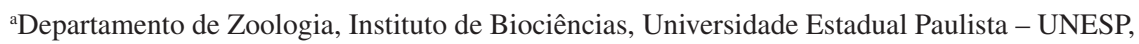 \\ Distrito de Rubião Júnior, CEP 18600-000, Botucatu, SP, Brazil

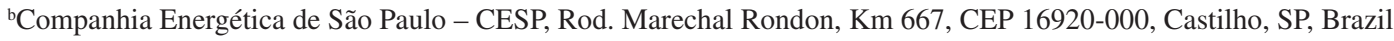 \\ *e-mail: ajorcin@ibb.unesp.br
}

Received March 19, 2007 - Accepted May 17, 2007 - Distributed February 28, 2009

(With 5 figures)

\begin{abstract}
This study is part of the limnological monitoring undertaken by the Energy Company of the State of São Paulo (CESP) during the filling up process of the Porto Primavera Reservoir (Hydroelectric Power Plant Engenheiro Sérgio Motta). This reservoir, located in the high Paraná River between the States of São Paulo and Mato Grosso do Sul, is the fourth largest in the country. The first filling up phase started in December 1998 and the second phase in March 2001. Samples for benthic community and sediment characteristics analysis were quarterly collected between August of 1999 and November 2001 and also in August of 2002 (11 sampling campaigns). Samplings were carried out at 13 stations distributed in the reservoir, and at one point located downstream of the dam. 128 invertebrate taxa were identified, being Mollusca, Annelida, Insecta and Nematoda the dominant groups during almost the whole study period. Insecta was the best represented class (9 different orders), and Diptera contributed with higher number of taxa, 63. The exotic species of bivalve Corbicula fluminea was recorded in all sampling stations showing its great capacity to colonize new habitats in the neotropical region. Noticeable variations in the fauna density were observed, considering both different periods and locations. The maximum density of organisms (mean value of 7812 ind. $\mathrm{m}^{-2}$ ) was recorded in the center of the reservoir, and the minimum (mean value 9 ind $\mathrm{m}^{-2}$ ) in the more lacustrine area near the dam. The greatest species richness per sample (24 taxa) was observed in the reservoir upstream (fluvial zone). The maximum diversity (Shannon-Wiener Index) per station/period, 3.82 and 3.86 bits.ind $^{-1}$, were calculated in the transitional river/reservoir zone during the beginning (August 1999) and in the reservoir central zones in the end (August 2002) of the filling up period, respectively. There was no clear relation between the distribution of the different faunistic groups and the sediment granulometric characteristics. However, the decrease or even total absence of organisms was observed at stations with high organic matter concentration $(>40 \%)$ in a low degradation state (coarse detritus). This fact may be related to the lack of sediment deposits, which would cause difficulties to the fixation of the benthic fauna. Additionally, in those conditions more reduced chemical conditions are expected in function of the intense decomposition process of the flooded vegetation.
\end{abstract}

Keywords: zoobenthos, sediments, filling up, Porto Primavera Reservoir.

\section{Distribuição espacial e temporal da comunidade zoobentônica durante o período de enchimento do Reservatório de Porto Primavera (Rio Paraná, Brasil)}

\section{Resumo}

Este estudo é parte do monitoramento limnológico empreendido pela Companhia Energética do Estado de São Paulo (CESP) durante o processo de enchimento do reservatório de Porto Primavera (Usina Hidrelétrica Engenheiro Sérgio Motta). Este reservatório, localizado no alto rio Paraná, entre os Estados de São Paulo e Mato Grosso, é o quarto maior do país. A primeira etapa de enchimento do lago começou em dezembro de 1998 e a segunda em março de 2001. Amostras para a análise da comunidade bentônica e das características sedimentológicas foram coletadas trimestralmente entre agosto de 1999 e novembro de 2001 e também em agosto de 2002 (11 campanhas). As coletas foram feitas em 13 estações de amostragem distribuídas no reservatório e em uma localizada a jusante da barragem. 128 táxons de invertebrados foram encontrados, sendo Mollusca, Annelida, Insecta e Nematoda os grupos dominantes durante praticamente todos os meses analisados. A classe Insecta foi a melhor representada, com 9 diferentes ordens, dentro das quais os Diptera contribuíram com a ocorrência de 63 táxons. A espécie exótica de bivalve Corbicula fluminea foi registrada em todas as estações de amostragem mostrando sua grande capacidade para colonizar novos habitats em regiões neotropicais. Variações consideráveis na densidade da fauna foram observadas para os diferentes períodos e locais analisados. A densidade máxima (média de 7812 ind. $\mathrm{m}^{-2}$ ) foi registrada no centro do reservatório enquanto que as densidades mínimas foram registradas na zona lacustre próxima à barragem (média de 9 ind. $\mathrm{m}^{-2}$ ). A maior riqueza de espécies por 
local/período (24 táxons) foi encontrada no trecho superior do reservatório (trecho fluvial). A diversidade máxima foi observada nas zonas superior e central do reservatório, com valores de 3.82 e 3.86 (bits.ind ${ }^{-1}$ ) no início (agosto/1999) e final (agosto/2002) do processo de enchimento, respectivamente. Não foi encontrado um padrão de distribuição dos grupos faunísticos que pudesse estar associado com a textura granulométrica dos diferentes locais amostrados. Por outro lado, constatou-se a diminuição, ou mesmo a não ocorrência de organismos, nas estações com elevada concentração de matéria orgânica (>40\%) em baixo estado de degradação (grandes detritos vegetais). Tal fato pode estar relacionado com a falta de depósitos de sedimentos, dificultando a fixação de organismos da fauna bentônica, bem como com condições químicas mais redutoras em função da intensidade dos processos de decomposição da fitomassa inundada.

Palavras-chave: zoobêntos, sedimentos, enchimento do reservatório, Porto Primavera.

\section{Introduction}

The construction of large reservoirs in a river results in major ecological transformations, including changes in its main channel and variations in the water flow pattern, such as the decrease of the current velocity in the areas next to the dams. In addition to the original variability found in a river bed, different sedimentological structures may be settled along the reservoir due to the new physical conditions. The water quality coming into large reservoirs also varies as a function of the biogeophysical characteristics present in the watershed. Thus, the variability in loads of dissolved or particulate solids, for example, typically reflect geological variations, use of the adjacent land and the precipitation - evaporation balance (Rice et al., 2001). These interferences change the system morphometry, its physical and chemical characteristics and also the functioning of the aquatic biota with the substitution of the fauna and flora components (Tundisi et al., 1999; Bicudo et al., 2006).

Gumiero and Salmoiraghi (1998) showed that both abundance and biomass of different benthic communities varied significantly when comparing regulated environments (dammed up) to non regulated ones. The authors concluded that dams lead to discontinuity and to considerable changes in communities along a longitudinal gradient.

The soil inundation, vegetation decomposition and detritus accumulation in the first phases of the filling up of the reservoir causes an important increment in densities of benthic invertebrates, but with a low richness of species (Brandimarte et al., 1999). Afterwards, a diversity increment is expected, as well as changes in the dominant species, a fact related to the stability processes after some period of time (Vorshell and Simmons, 1984).

Voshel and Simmons (1984), when studying the colonization process and the benthic species succession in a new reservoir, have found that it is possible to classify the macro invertebrates into primary and secondary colonizers. The primary colonizers would be facultative species coming from the previous lotic ecosystem. The secondary colonizers would be those species that became abundant after the second or third year of the filling up of the reservoir.

The aim of the present work is to analyze the zoobenthic community structure - composition, distribution, abundance and diversity, over the filling up period of the Porto Primavera Reservoir.

\section{Material and Methods}

\subsection{Study area}

Porto Primavera reservoir, (Electric Power Plant Engenheiro Sérgio Motta), is located in the Paraná River between the coordinates $53-52^{\circ} \mathrm{W}$ and $22-22^{\circ} 30^{\prime} \mathrm{S}$. The dam is $28 \mathrm{~km}$ upstream of the Paranapanema River mouth, between the cities of Rosana, in the State of São Paulo, and Batayporã and Anaurilândia in the State of Mato Grosso do Sul (Figure 1). The construction of the hydroelectric power plant started in 1980, but the first filling up stage of the lake began only in December 1998. In March of 2001, the second filling up stage occurred, reaching the operational level $257 \mathrm{~m}$ (a.s.1.) in 2003. The reservoir area has $2,250 \mathrm{~km}^{2}$ with an accumulated water volume of 20 billion $\mathrm{m}^{3}$, and a total length in the longitudinal axis of $250 \mathrm{~km}$. Five cities in the State of Mato Grosso do Sul and 16 cities in the State of São Paulo were flooded by the reservoir construction.

\subsection{Methodology}

The samples for zoobenthos and sediments analysis were quarterly collected between August 1999 and November 2001, and also in August 2002 after the second filling up stage of the lake, performing eleven sampling campaigns. Fourteen sampling stations were determined (Figure 1), most of them distributed in transversal transects, except the station number 14 and 13. This last one was located downstream of the dam.

At each station, 4 sediment samples were collected with a Van Veen type dredger $\left(0.0036 \mathrm{~m}^{2}\right)$, three of which were used for analyzing the zoobenthos and one for analyzing the sediment. For biotic analysis the sampled sediment was sieved $(250 \mu \mathrm{m})$ and fixed with formalin $4 \%$. Samples for sediment analysis were frozen until laboratory analysis.

Granulometric analysis for textural classification, percentage of the different sedimentological fractions and mean grain diameter, as well as for organic matter proportion, were performed according to Håkanson and Jansson (1983).

Samples for fauna analysis were rewashed at the laboratory in order to remove the formalin and remaining sediments and detritus. Rosa de Bengala pigment was used in order to facilitate posterior triage and the individuals found were conserved in alcohol $70 \%$.

Wiederholm (1983); Mansur et al. (1987); Brinkhurst and Marchese (1989); Pennak (1989); Epler (1992); Lopretto and Tell (1995); Trivinho-Strixino and Strixino (1995); Merrit and Cummings (1996) were the main references used for the taxonomical identification. 


\section{Results}

\subsection{Water column depth, sediment texture and organic matter content}

Wide variation of the local depth at the sampling stations was observed during the filling up of the reservoir. At stations 1 and 6 (reservoir upper zone), the smallest sampling depths (from 2.5 to $8 \mathrm{~m}$ ) were found. Station 11 , near the dam, presented the highest values, around $25 \mathrm{~m}$, mainly at the end of the filling up process. However, for most sampling stations $(2,3,4,5,6,7,8,10,11$ and 12) certain stability in terms of water column depth was attained, mainly from May 2001 to August 2002.

Through the sediment analysis it was possible to detect the high heterogeneity of the reservoir, both in space and over time. Except for station 14, where the textural classification of the sediment corresponded to silt/clay, the other points located in the center and upper zone of the reservoir were characterized by the presence of coarse sediment, classified between fine sand and gravel. The stations in the lacustrine zone and downstream the dam had sediment with lower size particles, varying between fine sand and silt/clay (Table 1).

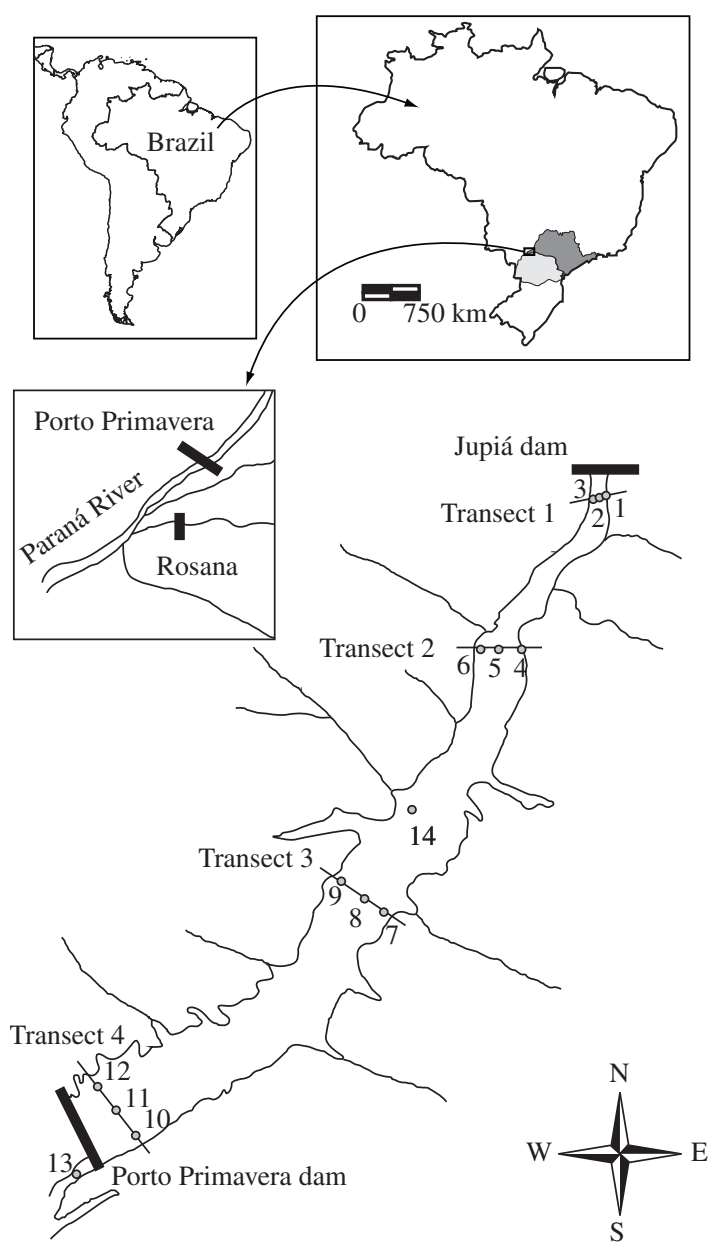

Figure 1. Localization of the Porto Primavera Reservoir and the sampling points distribution.
The organic matter content in the sediments oscillated from 0\% (not detected), such as at station 4 in August 2000, up to values of $49.25 \%$ at station 9, also in August 2000. Figure 2 shows the average values, and standard deviation, of the organic matter content determined for the different sampling periods. An increment of organic sediments seems to occur towards the dam. The high temporal variability of this parameter is also noticeable, specially at stations 9 and 12 .

\subsection{Benthic fauna}

A total of 128 taxa were found at the sediment samples, considering all sampling stations and periods. The following groups were represented: Mollusca, Annelida, Crustacea, Acarina, Nematoda, Turbellaria, Nemertinea and Insecta.

Mollusca, Annelida (Oligochaeta and Hirudinea), Nematoda and Insecta were found at almost all sampling stations, at least in one of the sampling periods. Among the Mollusca, Corbicula fluminea (Muller, 1776) was the most representative of the group, being found in all the sampling stations, followed by the gastropod Melanoides tuberculatus (Muller, 1774), that was found at 8 sampling stations (Table 2).

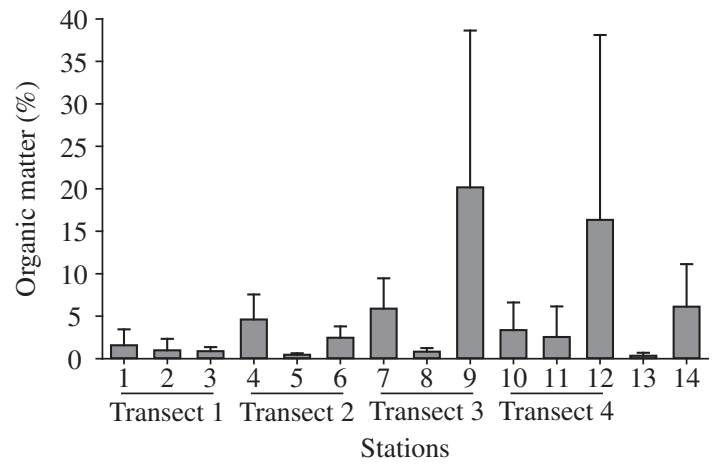

Figure 2. Graphic representation of the organic matter variation at the sampling stations (bar represents mean value, line represents the standard error).

Table 1. Textural characteristics at the different sampling stations (mean values between the sampling periods).

\begin{tabular}{rccc}
\hline Station & $\begin{array}{c}\text { Textural } \\
\text { classification }\end{array}$ & $\begin{array}{c}\text { Sand/gravel } \\
\text { percentage }\end{array}$ & $\begin{array}{c}\text { Silt/clay } \\
\text { percentage }\end{array}$ \\
\hline 1 & gravel & 99.39 & 0.61 \\
2 & gravel & 99.8 & 0.2 \\
3 & gravel & 99.0 & 1.0 \\
4 & fine sand & 80.9 & 19.1 \\
5 & medium sand & 98.55 & 1.45 \\
6 & gravel & 96.15 & 3.85 \\
7 & fine sand & 84.4 & 15.6 \\
8 & fine sand & 92.4 & 7.6 \\
9 & medium sand & 99.7 & 0.6 \\
10 & fine sand & 87.65 & 12.35 \\
11 & fine sand & 78.4 & 21.6 \\
12 & silt/clay & 44.2 & 55.8 \\
13 & fine sand & 98.75 & 1.25 \\
14 & silt/clay & 54.95 & 45.05 \\
\hline
\end{tabular}


Table 2. List of the benthic organisms found at the different sampling stations.

\begin{tabular}{|c|c|c|c|c|c|c|c|c|c|c|c|c|c|c|}
\hline Taxon/Station & 1 & 2 & 3 & 4 & 5 & 6 & 7 & 8 & 9 & 10 & 11 & 12 & 13 & 14 \\
\hline \multicolumn{15}{|l|}{ Mollusca } \\
\hline \multicolumn{15}{|l|}{ Bivalvia } \\
\hline Corbicula fluminea & + & + & + & + & + & + & + & + & + & + & + & + & + & + \\
\hline Anodontites & + & & & & & & & & & & & & & + \\
\hline Gundlachia & & & + & & & & & & & & & & & + \\
\hline Sphaeridae & & & & & & & & & + & & + & & & \\
\hline \multicolumn{15}{|l|}{ Gastropoda } \\
\hline Potamolithus & + & + & + & + & & + & + & & & & & & & \\
\hline Planorbidae & + & & & & & & & & & & & & & \\
\hline $\begin{array}{l}\text { Aylacostoma behni Hylton } \\
\text { Scott, } 1951\end{array}$ & + & & + & & + & + & & & & & & & & \\
\hline Melanoides tuberculatus & + & + & & + & & + & + & & & + & & & + & + \\
\hline \multicolumn{15}{|l|}{ Annelida } \\
\hline \multicolumn{15}{|l|}{ Oligochaeta } \\
\hline Homochaeta & + & + & & + & & + & + & + & + & + & + & & & \\
\hline Pristinella & + & & + & + & + & + & + & + & + & + & + & & + & + \\
\hline Stylaria & & & & & & & + & & & & & & & \\
\hline Pristina & + & & + & + & & & & & & & + & + & + & \\
\hline Amphichaeta & & + & & + & & & + & + & + & & & & & \\
\hline Allonais & & & + & & & & & & & & & & & \\
\hline Bratislavia & & & & & & + & & & & & & & & + \\
\hline Stephensoniana & + & + & + & & & & & & & & & & + & \\
\hline Naididae n/i & + & + & + & + & + & + & & + & + & & & & + & + \\
\hline Narapa bonettoi & & & & + & + & + & & + & & & + & & + & \\
\hline Enchytraidae & & & + & & & & & & & & & & & \\
\hline Haplotaxidae & & & & & & & & & & & & & + & \\
\hline Tubificidae & & & & + & & + & & + & + & + & & & & + \\
\hline \multicolumn{15}{|l|}{ Hirudinea } \\
\hline Batracobdella & & & + & + & & & + & + & + & & + & + & + & + \\
\hline Placobdella & + & + & & + & & & & & + & + & + & & & + \\
\hline Glossiphonidae n/i & + & + & + & + & & & + & + & & + & & & & + \\
\hline \multicolumn{15}{|l|}{ Crustacea } \\
\hline \multicolumn{15}{|l|}{ Decapoda } \\
\hline Palemonetes & & & & & & & + & + & & & & & & \\
\hline Isopoda & & & & & & & & + & & & & & & \\
\hline Ostracoda & + & + & + & + & & + & + & + & + & + & + & + & + & + \\
\hline \multicolumn{15}{|l|}{ Copepoda } \\
\hline Harpacticoida & & & & & & & & & + & & & & & \\
\hline Acarina & + & + & & + & & + & & & + & + & + & & & \\
\hline Nematoda & + & + & + & + & + & + & + & + & + & + & + & + & + & + \\
\hline Nemertinea & & & & & & & & & & & & & & + \\
\hline \multicolumn{15}{|l|}{ Turbellaria } \\
\hline Dugesia & + & + & + & + & + & & + & & & & & & & \\
\hline \multicolumn{15}{|l|}{ Insecta } \\
\hline \multicolumn{15}{|l|}{ Coleoptera } \\
\hline Mycrocilloepus & + & + & & + & & + & & & & & & & & \\
\hline Elmidae n/i & + & + & + & + & & + & & & & & & & & + \\
\hline Psepheridae & & & & & & + & & & & & & & & + \\
\hline
\end{tabular}


Table 2. Continued...

\begin{tabular}{|c|c|c|c|c|c|c|c|c|c|c|c|c|c|c|}
\hline Taxon/Station & 1 & 2 & 3 & 4 & 5 & 6 & 7 & 8 & 9 & 10 & 11 & 12 & 13 & 14 \\
\hline Gyrinidae & & & & & + & + & & & & & & & & \\
\hline \multicolumn{15}{|l|}{ Trichoptera } \\
\hline Orthotrichia & + & + & & & & & & & & & & & & \\
\hline Leptonema & + & + & & + & & & & & & & & & + & + \\
\hline Setodes & + & & & & & & & & & & & & & \\
\hline Smicridea & & + & + & & & + & & & & & & & + & \\
\hline Parapsyche & + & + & & & & & + & & + & & & & & \\
\hline Zumatrichia & & & & & & & & & & + & & & & \\
\hline Leucotrichia & & & + & & & & & & & + & & & & \\
\hline Helicopsyche & & & + & + & & & & & & & & & & \\
\hline Odontoceridae n/i & & + & + & & & & & & & & & & & \\
\hline Neotrichia & & + & & & & & & & & & & & & \\
\hline Oecetis & + & + & + & + & & & & & & & & & + & + \\
\hline Nectopsyche cf. & & & + & & & + & & & & & & & & \\
\hline Neureclipses & + & & + & & & & + & & & & & & & + \\
\hline Philopotamidae & + & & & & & & + & & & & & & & \\
\hline \multicolumn{15}{|l|}{ Ephemeroptera } \\
\hline Caenis & & & + & & & & & & & & & & & \\
\hline Campsurus & & & & + & & & & & & & & & & \\
\hline Tricorythodes & + & + & + & & & & & + & + & & & & & + \\
\hline Leptohyphes & + & + & + & & & + & & & & & & & & + \\
\hline Ephemerella & + & + & + & & & & & & & & & & & + \\
\hline Oligoneuriidae $\mathrm{cf}$. & & & + & & & & + & & & & & & & \\
\hline \multicolumn{15}{|l|}{ Orthoptera } \\
\hline Ellipes (?) & & & + & & & & & & & & & & + & \\
\hline \multicolumn{15}{|l|}{ Collembola } \\
\hline Isotomus & + & & & & + & + & & & & & & & + & + \\
\hline Sensiphorura cf. & & & & & & & & & & + & + & & & \\
\hline Hemiptera & & + & & & & & + & & & & & & & + \\
\hline \multicolumn{15}{|l|}{ Buenoa } \\
\hline Lepidoptera & & & & & & + & & & & & & & & \\
\hline \multicolumn{15}{|l|}{ Odonata } \\
\hline Gomphidae & + & & + & & & & & & & & & & & \\
\hline Aphylla & + & & & + & & + & & & & & & & & + \\
\hline \multicolumn{15}{|l|}{ Diptera } \\
\hline Chaoborus & & & & & & & & & & & & + & & \\
\hline Ablabesmyia (Karelia) & + & + & + & & + & + & + & + & + & & & & & + \\
\hline $\begin{array}{l}\text { Ablabesmyia annulata Say, } \\
1823\end{array}$ & + & & & & & & & & & & & & & + \\
\hline Axarus & & & & & + & + & & & & & & & & + \\
\hline Ceratopogonidae & + & & & + & + & + & + & + & & & & & + & + \\
\hline Chironomus gr. riparius & & & & & & + & + & & & & + & & & + \\
\hline Cladopelma & & & & & + & + & & & & & & & & \\
\hline Cladotanytarsus & & & & & & & + & & & & & & & \\
\hline Coelotanypus & + & & + & & & + & & + & & + & + & & & \\
\hline Clinotanypus & + & & & & & & & & & & & & & + \\
\hline Cricotopus sp.1 & & & & + & & + & & & & & & & & + \\
\hline Cricotopus sp.2 & & & & & & & + & & & & & & & \\
\hline Cryptochironomus sp.1 & + & + & + & + & + & + & + & & & & & & & \\
\hline
\end{tabular}


Table 2. Continued...

\begin{tabular}{|c|c|c|c|c|c|c|c|c|c|c|c|c|c|c|}
\hline Taxon/Station & 1 & 2 & 3 & 4 & 5 & 6 & 7 & 8 & 9 & 10 & 11 & 12 & 13 & 14 \\
\hline Cryptochironomus sp.2 & + & & & + & & & & + & + & & & & & + \\
\hline Demicryptochironomus & & & & & & & & & & & & & & + \\
\hline Dicrotendipes sp.1 & + & + & + & + & + & + & & & & & & & & \\
\hline Dicrotendipes sp.2 & & & + & & + & + & & + & & & & & & \\
\hline $\begin{array}{l}\text { Djalmabatista pulcher } \\
\text { Johansen, } 1908\end{array}$ & & & & + & + & & & + & & & & & & + \\
\hline Djalmabatista sp. 2 & + & & + & + & + & + & + & & & & + & & & + \\
\hline Gênero A sp. 2 & + & & + & & & + & + & & & & & & + & \\
\hline Gênero A sp.4 & & & & + & & + & + & & & & & & & + \\
\hline Gênero B & & + & + & + & + & + & & & & + & + & & & \\
\hline Glyptotendipes & & & & & & & & & & & & & + & \\
\hline $\begin{array}{l}\text { Goeldichironomus xiborena } \\
\text { Fittkau, } 1965\end{array}$ & & & & + & & & & & & & + & + & & + \\
\hline Harnischia & + & + & & & & + & & & & & & & & + \\
\hline $\begin{array}{l}\text { Chironomus gr. salinarius } \\
\text { Kieffer, } 1915\end{array}$ & & & & & & + & & & & & + & & & \\
\hline Labrundinia & & & & & & & & & & & + & & & \\
\hline Larsia & & & & & & & & & & & & & & + \\
\hline Lopescladius & & + & + & & + & & & + & & & & & & + \\
\hline Manoa & & & & & & & & & & & & & & + \\
\hline Microchironomus & & & & & & & & & & & + & & & \\
\hline Microtendipes & & & & + & & & & & & & & & & \\
\hline Monopelopia & + & & & + & & + & & & & & & & & \\
\hline Macropelopia & & & & & & & & & & & + & & & \\
\hline Nanocladius & & & & & + & & + & & & & & & & + \\
\hline Nimbocera sp.3 & & & & & & + & & & & & & & & \\
\hline Nilothauma sp.1 & & & + & & + & + & & & & & & & & \\
\hline Nilothauma sp.2 & + & & + & & & & & + & & & & & & \\
\hline Orthocladiinae & + & + & + & + & + & + & & + & & & + & & + & \\
\hline Parachironomus & & + & + & & + & + & & + & & + & & & + & \\
\hline Paralauterboniella & & & & + & & + & & + & + & & + & & & + \\
\hline Parametriocnemus & + & & & & & & & & & & & & & \\
\hline Pentaneura & + & + & & & + & + & + & & + & + & & & & \\
\hline Polypedilum(Polypedilum)sp.1 & + & & & + & & + & & & & & & & & + \\
\hline Polypedilum(Polypedilum)sp.2 & + & + & + & + & & + & & + & & & & & + & + \\
\hline Polypedilum (Tripodura) & + & + & + & + & + & + & + & + & + & & & & & + \\
\hline Polypedilum gr. fallax & & & & & & & & & & & & & + & \\
\hline Procladiini (n/i) & & & & & & + & & + & & & & & & \\
\hline Procladius & + & & & & & + & & + & & & & & & + \\
\hline Pseudochironomus & + & & + & & & & & & & & & & & + \\
\hline Rheotanytarsus & + & + & & & + & & & & & & & & & \\
\hline Rheotanytarsus sp.1 & & & + & & + & & & + & & & & & & + \\
\hline Saetheria? & & & + & & + & + & + & + & + & & & & + & \\
\hline Stelechomyia & + & & + & & & & & & & & & & & \\
\hline Stempellina & & & & & & & & & & & + & & & \\
\hline Stenochironomus & & & & + & & + & + & & + & & & & & \\
\hline Tanypodinae n/i & & + & + & + & + & + & + & + & + & & + & & + & + \\
\hline Tanytarsini n/i & + & + & + & & + & + & & + & & & + & & & + \\
\hline Tanytarsus & + & + & + & & + & + & + & + & & & & & + & \\
\hline Thienemaniella (?) sp.3 & & & & & & + & & & & & & & & + \\
\hline
\end{tabular}


Table 2. Continued...

\begin{tabular}{|c|c|c|c|c|c|c|c|c|c|c|c|c|c|c|}
\hline Taxon/Station & 1 & 2 & 3 & 4 & 5 & 6 & 7 & 8 & 9 & 10 & 11 & 12 & 13 & 14 \\
\hline Tribelos sp.2 & & + & & & & + & & & & & & & & + \\
\hline Chironomidae pupa & & + & + & & + & + & & + & + & & + & & + & + \\
\hline Tipulidae & & & & & & & & & & & & & + & \\
\hline Total taxa & 57 & 43 & 53 & 43 & 33 & 60 & 34 & 35 & 24 & 16 & 27 & 7 & 28 & 54 \\
\hline
\end{tabular}

+: indicates presence; $\mathrm{n} / \mathrm{i}$ : not identified.

Among the Annelida, the Oligochaeta was the predominant class, with 13 identified taxa. In this class, Pristinella occurred in almost all sampling stations. The Crustacea were represented mainly by Ostracoda, which were widely distributed in the reservoir. Occasionally, Decapoda, Isopoda and Copepoda were also registered. Nematoda was also found in almost the entire reservoir. Other groups such as Acarina, Nemertinea and Turbellaria were less frequent.

Insecta were represented by 9 orders: Coleoptera, Trichoptera, Ephemeroptera, Orthoptera, Collembola, Hemiptera, Lepidoptera, Odonata and Diptera. Sixtythree taxa from this last order were recorded, heterogeneously distributed among the different periods and stations of sampling.

A high number of taxa occurs in the upper zone of the reservoir (Figure 3), among stations 1 to 6, including station 14 . In the center of the reservoir, and specially near the dam, there was a decrease in the number of taxa. The maximum richness found per station/period was registered in station 1, with 24 taxa in August 2002, followed by station 14 with 21 taxa for the same period.

In the reservoir upper zone it was observed that the different taxonomic groups observed at the beginning of the filling up phase continued to be found until the end of the study period. In the central region of the reservoir, the occurrence of the distinct zoological groups was not regular over the sampling periods. In the lacustrine zone near the dam the taxonomic richness was lower compared to the other compartments, and some common taxa present in the upper points were not observed. For the zone downstream of the dam (station 13) the greatest richness values were registered during the first three sampling months (August and November, 1999 and February, 2000). Some groups such as Gastropoda and Trichoptera disappeared from May 2000 onwards.

The density of the benthic organisms had a high variation at some sampling stations during the study period (Figure 4). High density values were found at station 8 , located in the center of the reservoir, specially in February 2001, when the number of organisms reached 7812 ind. $\mathrm{m}^{-2}$. At stations 3, 5, 6 and 13 peaks of high density were also recorded, with values of 4322, 4400, 4773 and 6275 ind. $\mathrm{m}^{-2}$, respectively.

The stations located near the dam (10, 11 and 12) had the smaller density of organisms, as well as low richness of species. In some sampling periods no organisms were registered.

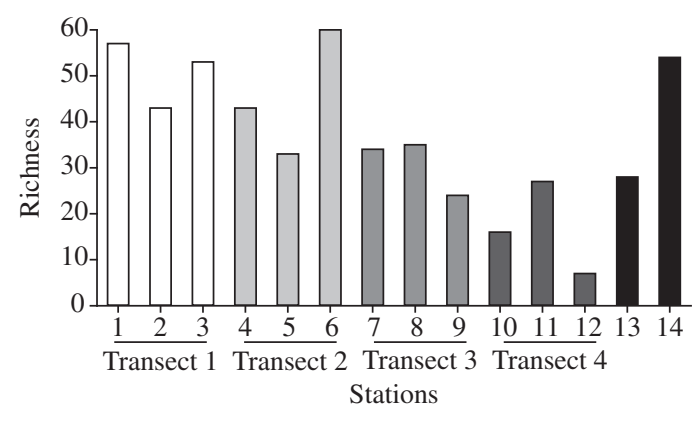

Figure 3. Cumulative zoobenthos richness at the sampling stations.

\subsection{Diversity}

There was a high oscillation of the diversity values over the studied period when the same sampling points (Figure 5) were considered. The diversity, mainly the minimum values, was generally higher in the upper zone of the reservoir, and then with a decreasing tendency towards the dam.

Stations 14 and 6 presented the maximum diversity values (3.86 in August 2002 and 3.82 bits ind $^{-1}$ in August 1999). Stations 1, 2 and 3, on different occasions, also presented relatively high values of diversity, 3.53, 3.61

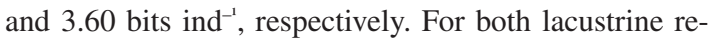
gion and downstream of the dam, the diversity values were generally low.

\section{Discussion}

During the filling up period of Porto Primavera Reservoir important changes in the sediment characteristics were observed, as well as in the structure of the benthic community. The water column depth had a lower variation at the sampling stations located in the center of the transversal sampling transects. Probably this fact is because there is certain coincidence of these points with the former Paraná River channel. Depth variation at the stations located next to the margins was higher, showing it to be more susceptible to the level oscillation during the filling up process.

The heterogeneity in the textural classification of the sediments of the reservoir comes mainly from its hydrodynamic characteristics. In the upper reservoir (river/reservoir transitional zone) the deposition of fine sediment does not occur due to the high water velocity. 
However, near to the dam, the lacustrine characteristic with lower influence of advective transportation favors the silt deposition. Such a fact has already been observed for other reservoirs in the high Paraná basin (Jorcin and Nogueira, 2005a, b). Nevertheless, despite the tendency of a higher accumulation of silt material and organic matter near the dam, an increment of these variables over the sampling period was not observed. Santos et al. (2006) have observed in the Canoas I and Canoas II Reservoirs (Paranapanema River, SP/PR) that there occurred a small increment of organic matter concentration in the sediments during the post-filling up phase, as well as an increment of the silt-clay proportion.

Organic matter concentration is directly related to the textural characteristics. In sandy sediments, the organic content is lower than in sediments with a higher proportion of silt and clay (Håkanson and Jansson, 1983). This relation was observed in Porto Primavera Reservoir, where it was detected that organic matter deposition is lower at more riverine stations in relation to the stations
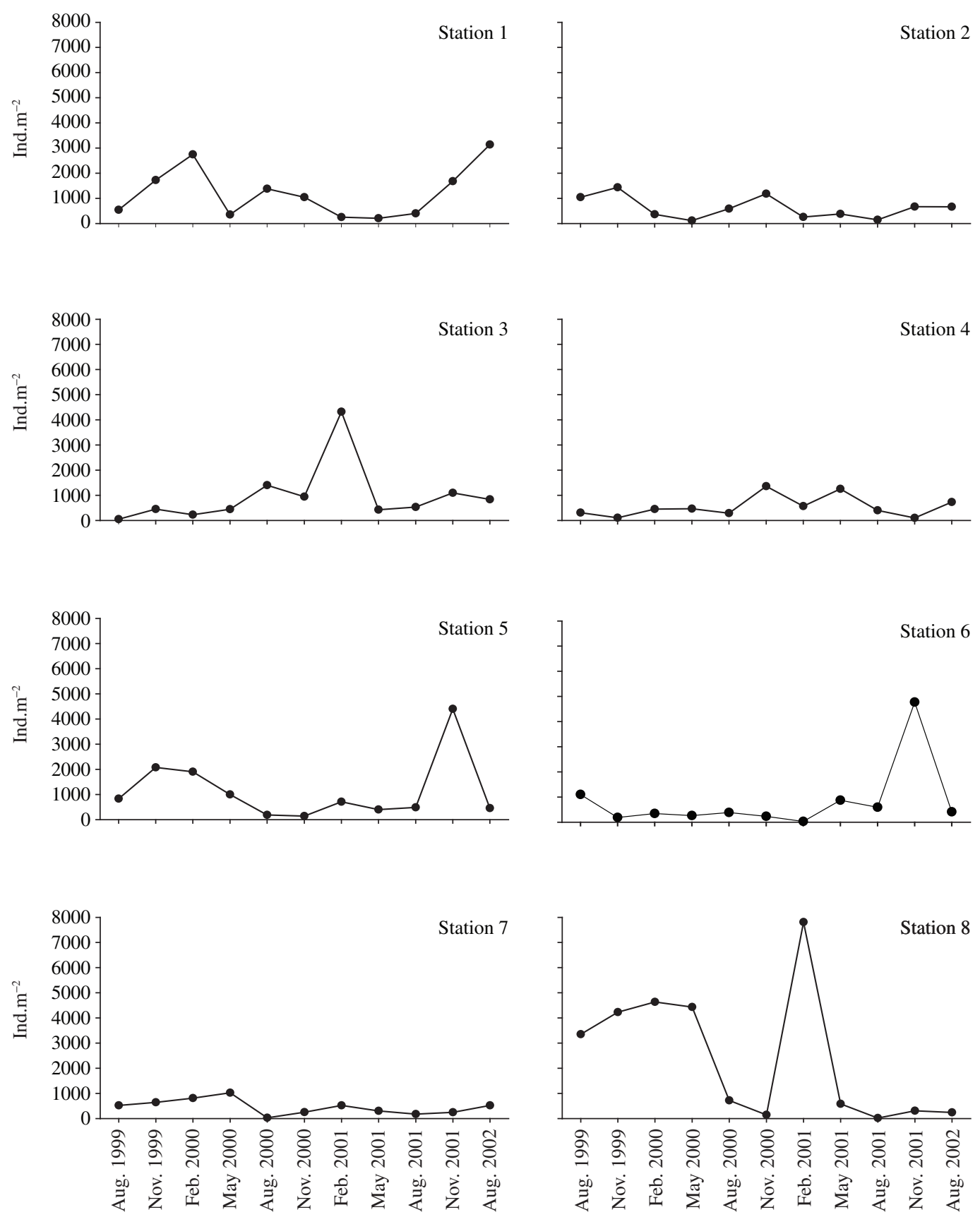

Figure 4. Density variation (ind. $\mathrm{m}^{-2}$ ) of the benthic organisms over the study period at the different sampling stations. 

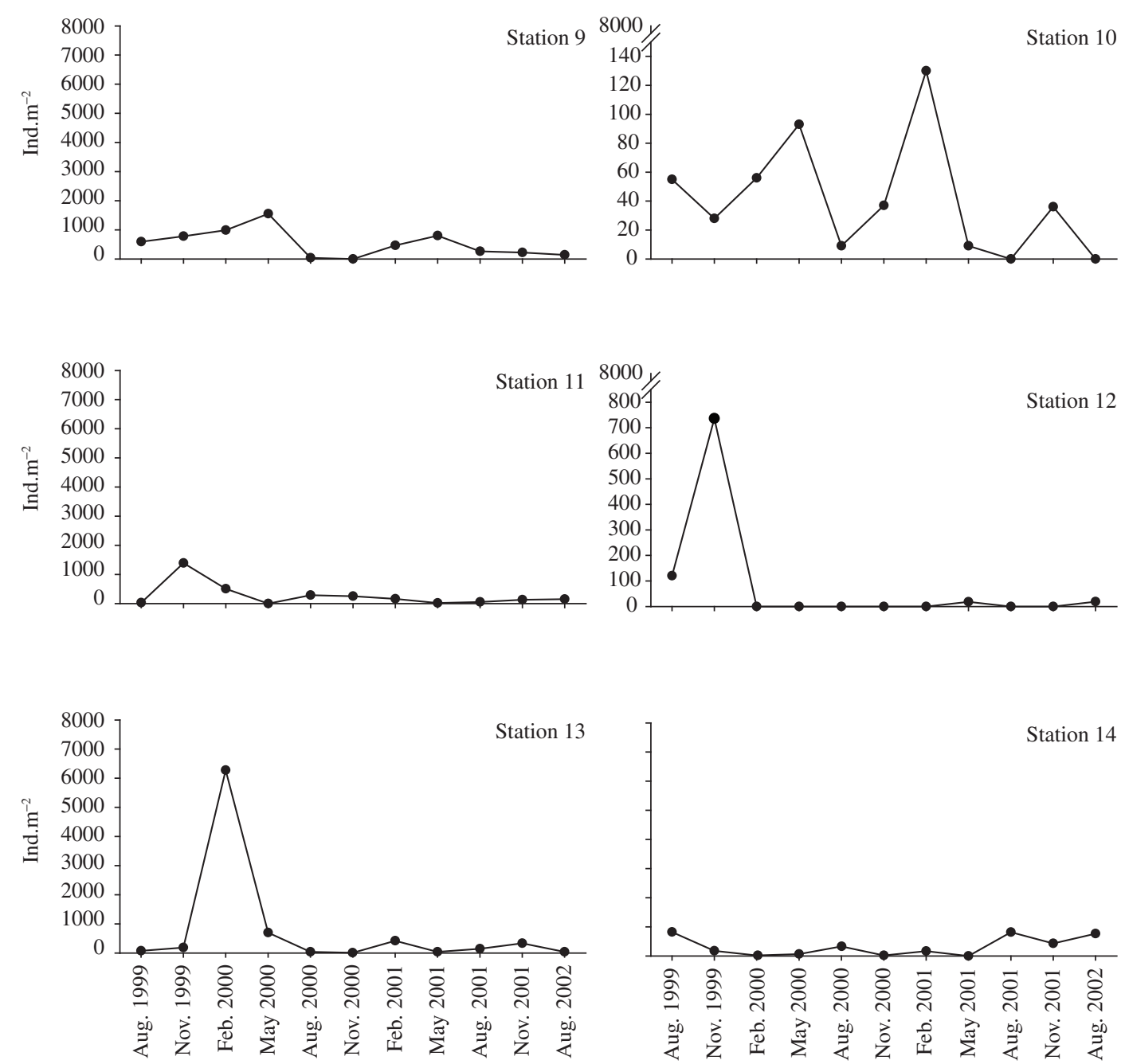

Figure 4 (Continued). Density variation (ind. $\mathrm{m}^{-2}$ ) of the benthic organisms over the study period at the different sampling stations.

near to the dam. For station 14, located in the central zone of the reservoir, the silt characteristics and the higher concentration of organic matter may be related to the depositional material coming from the Taquaruçu River (MS).

The results show that a decrease in the number of taxa of benthic organisms occurred in the direction of the dam. Factors such as depth increment and organic matter accumulation in sediments affect distribution and abundance of organisms. In deeper zones the light penetration in the water column decreases, causing many benthic organisms not to adapt to the prevailing conditions. The decrease and even disappearance of organisms from benthic fauna, in function of the depth increment were also observed by Santos and Henry (2001) for Jurumirim Reservoir. Increase in depth may cause a reduction of the oxygen concentration near to the bottom, taking the sediment to anoxic conditions. In such conditions, organisms like Coleoptera, Trichoptera, Ephemeroptera, for example, do not occur (Roldán, 2006).
Voshell and Simmons (1984), studying the colonization and succession process of benthic species in a new reservoir, observed the disappearance of the original riverine species and the appearance of lacustrine ones occurring approximately two years after the reservoir being formed. According to the authors, the changes in the biota composition and abundance after the reservoir filling up, when the terrestrial characteristics tend to disappear, take approximately two or three years. Changes in composition and density of the benthic taxonomic groups were also observed by Brandimarte et al. (1999) throughout the pre and post- filling up phases of Mogi-Guaçu Reservoir (SP).

For Porto Primavera Reservoir, taxonomical substitution regarding major zoological groups was not observed, mainly in the upper and central zones of the reservoir. However, in the lacustrine (dam) zone and downstream of the reservoir, the disappearance of some taxa was registered. In the dam zone, such a fact might be related to the depth increment already mentioned 


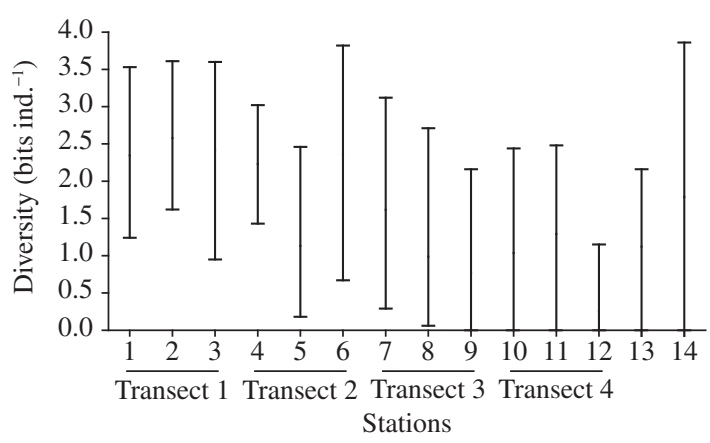

Figure 5. Minimum and maximum diversity values of benthic fauna at the sampling stations.

and to organic matter accumulation leading to more reduced chemical conditions. The excess of organic matter, caused by degradation processes of preexistent vegetation in the region before the filling up of the lake, as well as the deposition of suspended material, do not favor the establishment of a benthic with high richness. Only physically adapted organisms, resistant to low luminosity and oxygen levels could be able to live in these regions. In this case, species belonging to the Oligochaeta and Nematoda classes might be successful (Lopretto and Tell, 1995).

In the reservoir downstream zone, the benthic community presented higher fluctuations in the number of taxa over time, showing an important decrease in richness mainly from 2001 onwards. For the last study period (August 2002), only Bivalvia and Oligochaeta were found at this sampling point. Brandimarte et al. (1999), studying the impoundment effects in the Mogi-Guaçu River, also verified that the downstream benthic fauna was seriously damaged.

In general, there was not a regular pattern of spatial and temporal variation in density, richness and diversity of the benthic organisms during the study period. It could be inferred, based on the obtained data, that major alterations regarding the structure of the benthic community of Porto Primavera Reservoir will not occur in the future. The tendency should be the establishment of a relatively constant community structure, similar to the one recorded during the last periods of study. The taxonomic composition should reach a stability point as observed by other authors studying filling up processes in reservoirs (e.g. Voshell and Simmons, 1984). Nevertheless, oscillations in richness can be expected when the distinct reservoir compartments are considered, until the stabilization of the unconsolidated sediments start to offer better conditions for the invertebrate fauna. Noticeable influence of seasonality is also expected, specially in the upper and middle zones of the reservoir, which are more susceptible to dry/wet conditions. Callisto et al. (2001, 2004) studying the macrobenthic community from Serra do Cipó (MG) found that structural and compositional modification of this community occurs due to changes in trophic resource availability. According to the authors, the physical disturbance of the substrate (observed in the rainy period) causes the resuspension of sediment on the bottom and, as a consequence, the modification of the functional trophic groups.

Finally, it is also important to consider that the benthic community is also susceptible to point and non-point alterations in water and sediment quality, and processes like the income of pollutant materials (e.g. pesticides, metals and sewage) must be continuously observed, in order to prevent damage both in richness and density of the organisms. In case of the occurrence of anoxic sediment accumulation, which may occur near to the dam due to great depth and high organic matter concentration, the benthic fauna may be directly affected, not only with a decrease of richness but also with a total disappearance of the organisms.

Acknowledgements - The authors wish to thank the Energy Company of the State of São Paulo (CESP) for the initiative to perform this study and for the additional information about the reservoir.

\section{References}

BICUDO, DC., FERRAGUT, C., CROSSETTI, LO. and BICUDO, CEM., 2006. Efeitos do represamento sobre a estrutura da comunidade fitoplanctônica do reservatório de Rosana, baixo rio Paranapanema, Estado de São Paulo. In Nogueira, MG., Henry, R. and Jorcin, A. (Org.). Ecologia de Reservatórios, impactos potenciais, ações de manejo e sistemas em cascata. São Carlos: Rima, 459 p.

BRANDIMARTE, AL., ANAYA, M. and SHIMIZU, GY., 1999. Comunidades de invertebrados bentônicos nas fases pré e pósenchimento em reservatórios: um estudo de caso no reservatório de aproveitamento múltiplo do rio Mogi-Guaçú (SP). In: Henry, R. (Ed.). Ecología de reservatórios: estrutura, função e aspectos sociais. Botucatu, SP: Fapesp/Fundibio.

BRINSHURST, RO. and MARCHESE, MR., 1989. Guide of the freshwater aquatic Oligochaeta of South and Central America. Colección Climax, no. 6, 179 p.

CALLISTO, M., MORENO, P. and BARBOSA, FAR., 2001. Habitat diversity and benthic trophic functional groups at Serra do Cipó, southeast Brazil. Brazilian Journal Biology, vol. 61, no. 2, p. 259-266.

CALLISTO, M., GOULART, M., MEDEIROS, AO., MORENO, P. and ROSA, CA., 2004. Diversity assessment of benthic macroinvertebrates, yeast and microbiological indicators along a longitudinal gradients in Serra do Cipó, Brazil. Revista Brasileira de Biologia = Brazilian Journal of Biology, vol. 64, no. 4, p. 743-755.

EPLER, JH., 1992. Identification manual for the larval Chironomidae (Diptera) of Florida. Orlando: Depart. of Environmental Regulation, 308p.

GUMIERO, B. and SALMOIRAGHI, G., 1998. Influence of an impoundment on benthic macroinvertebrate habitat utilization. Verh International Verein Limnology, vol. 26, p. 2063-2069.

HÅKANSON, L. and JANSSON, N., 1983. Principles of lake sedimentodology. Berlim: Sringer-Verlag, 316p.

JORCIN, A. and NOGUEIRA, MG., 2005a. Phosphate distribution in the sediments along a cascade of reservoirs 
(Paranapanema River, SE, Brazil). In: Serrano, L. and Golterman, HL. (Eds.) Phosphate in Sediments. Proceeding of the $4^{\text {th }}$ International Symposium. Leiden: Backhuys, p 77-86

JORCIN, A. and NOGUEIRA, MG., 2005b. Temporal and spatial patterns based on sediment and sediment-water interface characteristics along a cascade of reservoirs (Paranapanema River, south-east Brazil). Lakes and Reservoirs: Research and Management, vol. 10, p. 1-12.

LOPRETTO, EC. and TELL, G., 1995. Ecosistemas de aguas continentales. Metodologias para su estudio. Tomos I, II, III. Argentina: Ediciones Sur, 1401 p.

MANSUR, MCD., SCHULZ, C. and GARCES, LM., 1987. Moluscos Bivalves de água doce: identificação dos gêneros do Sul e Leste do Brasil. Acta Biologica Leopoldensia, vol. 9, no. 2, p. 181-202.

MERRIT, RW. and CUMMINS, KW., 1996. An Introduction to the Aquatic Insects of North America. Kendall: Hunt, 862 p.

PENNAK, RW., 1989. Freshwaterr invertebrates of the United States. Protozoa to Mollusca. New York: John Wiley \& Sons, Inc., $628 \mathrm{p}$.

ROLDÁN, G., 2006. Los macroinvertebrados acuáticos como indicadores de la calidad del agua. In Tundisi, JG., MatsumuraTundisi, T. and Galli, CS. (Eds.). Eutrofização na América do Sul: causas, conseqüências e tecnologias para gerenciamento e controle. São Carlos: IIE/GAIIE/Eutrosul.

RICE, SP., GREENWOOD, MT. and JOYCE, CB., 2001. Tributaries, sediment sources, and the longitudinal organization of macroinvertebrates fauna along river systems. Canadian Journal of Fisheries and Aquatic Sciences, vol. 58, no. 4, p. $824-840$.

SANTOS, CM. and HENRY, R., 2001. Composição, distribuição e abundância de Chironomidae (Diptera, Insecta) na represa de Jurumirim (rio Paranapanema - SP). Acta Limnologica Brasiliensia, vol. 13, no. 2, p. 99-115.

SANTOS, CM., FERREIRA, RS. and HENRY, R., 2006. Alterações na organização da comunidade bentônica no complexo Canoas (Rio Paranapanema - SP) durante as fases pré e pós enchimento. In Nogueira, MG., Henry, R. and Jorcin, A. (Orgs.). Ecologia de Reservatórios, impactos potenciais, ações de manejo e sistemas em cascata. São Carlos: Rima, 459p.

TRIVINHO-STRIXINO, S. and STRIXINO, G., 1995. Larvas de Chironomidae (Diptera) do Estado de São Paulo. Guia de Identificação e diagnose dos gêneros. São Carlos: PPG-ERN/ UFSCAR, 229p.

TUNDISI, JG., MATSUMURA-TUNDISI, T. and ROCHA, O., 1999. Limnologia de águas interiores. Impactos, Conservação e Recuperação de Ecossitemas Aquáticos. In Rebouças, A., Braga, B. and Tundisi, JG. (Eds.). Águas doces no Brasil. Capital ecológico, uso e conservação. São Paulo: Escrituras Editora.

VOSHELL Jr, JR. and SIMMONS Jr, GM., 1984. Colonization and succession of benthic macroinvertebrates in a new reservoir. Hydrobiologia, vol. 112, no. 1, p. 27-39.

WIEDERHOM, T., 1983. Chironomidae of the Holartic region. Keys and diagnosis. Entomologica Scandinava, Part 1: Larvae, supl. no. 19, 457p. 